
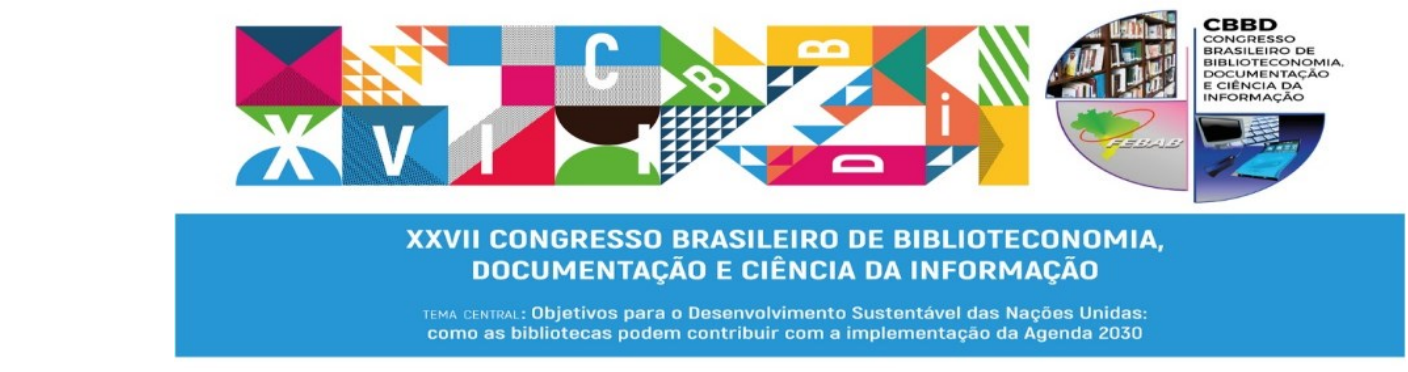

Eixo $2-3^{\circ}$ Fórum de Biblioteconomia Escolar

\title{
CRIAÇÃO, IMPLANTAÇÃO E AVALIAÇÃO DE UM PROGRAMA DE COMPETÊNCIA EM INFORMAÇÃO EM ALUNOS DO ENSINO FUNDAMENTAL
}

\author{
Daniela Spudeit \\ Docente da Graduação em \\ Biblioteconomia e do Programa de \\ Pós-graduação em Gestão da \\ Informação da Universidade do Estado \\ de Santa Catarina. Mestre em Ciência \\ da Informação pela Universidade \\ Federal de Santa Catarina. \\ E-mail: danielaspudeit@gmail.com
}

\section{Allana Freitas \\ Discente da Licenciatura em Biblioteconomia da Universidade Federal do Estado do Rio de Janeiro. E-mail: alanna.freitas@hotmail.com}

\section{Claudia Souza}

Discente do Bacharelado em Biblioteconomia pela Universidade Federal do Estado do Rio de Janeiro. E-mail: kraudya@gmail.com

\section{Nathália Romeiro}

Mestranda do Programa de Pósgraduação em Ciência da Informação do Instituto Brasileiro em Informação, Ciência e Tecnologia em convênio com a Universidade Federal do Rio de Janeiro.

E-mail: ntromeiro91@gmail.com

\section{Victor Rosa}

Discente da Licenciatura em Biblioteconomia pela Universidade Federal do Estado do Rio de Janeiro. E-mail: victor.soares.rosa@gmail.com

\section{RESUMO}

Apresenta o projeto de extensão 'Competência em Informação: implementação e avaliação de um programa para o âmbito escolar', desenvolvido por docentes e discentes dos cursos de Licenciatura e Bacharelado em Biblioteconomia da Universidade Federal do Estado do Rio de Janeiro no Colégio Pedro II, escola pública federal localizada na cidade do Rio de Janeiro. 0 projeto objetivou criar, implementar e avaliar um programa de Competência em Informação em escola pública com alunos de ensino fundamental. Consiste em uma pesquisa descritiva, bibliográfica e documental que busca subsídios teóricos nas diretrizes, padrões, programas existentes, entre outras fontes. Descreve o processo de elaboração do programa, alinhado a missão da instituição e aprimorado com a equipe da biblioteca e professores, que visou o desenvolvimento da competência em informação nos educandos do sexto ano. 0 projeto teve como tema as Olimpíadas e foi dividido em seis ações para serem realizadas em diferentes espaços educativos da instituição. Buscou-se desenvolver diferentes competências relacionadas à identificação das necessidades informacionais, busca, avaliação, análise e síntese da informação pelo uso de diferentes estratégias. Observa-se que os objetivos foram alcançados, porém a equipe observou pontos que devem ser melhorados para envolver mais os professores na realização de algumas atividades, além disso, o programa necessita de uma carga horária tempo maior para execução e avaliação.

Palavras-chave: Competência em Informação. Programa de Competência em Informação. Biblioteca Escolar. Ensino Fundamental.

CREATION, IMPLEMENTATION AND EVALUATION OF AN
INFORMATION LITERACY PROGRAM ON STUDENTS OF
ELEMENTARY SCHOOL 


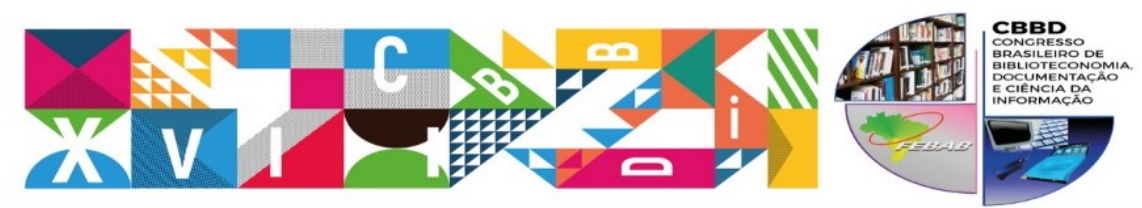

XXVII CONGRESSO BRASILEIRO DE BIBLIOTECONOMIA,

DOCUMENTAÇÃO E CIÊNCIA DA INFORMAÇÃO

TEMA CENTral: Objetivos para o Desenvolvimento Sustentável das Naçōes Unidas:
como as bibliotecas podem contribuir com a implementaçāo da Agenda 2030

ABSTRACT

It presents the extension project 'Information Literacy: implementation and evaluation of a program for the school environment', developed by teachers and students of the graduate courses in Library Science of the Federal University of the State of Rio de Janeiro at Colégio Pedro II, a public school in the city of Rio de Janeiro. The project aimed to create, implement and evaluate an Information Literacy program at a public school with elementary school students. It consists on a descriptive, bibliographical and documentary research that looks for theoretical subsidies in the guidelines, standards and the existing programs, among other sources. It describes the process of preparing the program, related to the mission of the institution and improved with the library staff and teachers, which aimed to develop the information literacy on the students of the sixth grade. The project had as theme Olympics Games and was divided in six actions to be realized in different educational spaces of the institution. Different information skills were tried to be developed. They were related to the identification of the information needs, search, evaluation, analysis and synthesis of information by using different strategies. It is observed that the objectives were achieved but the team observed points that can be improved throughout the execution of the program so that teachers can be more involved on the activities planned and that more time is needed to enable a more effective evaluation by students and teachers.

Keywords: Information Literacy. Information Literacy program. School library. Elementary school.

\section{INTRODUÇÃo}

Com o desenvolvimento das Tecnologias de Informação e Comunicação (TIC) no século XXI, observa-se a constituição de um novo habitus social, evidenciado através da mudança de sociedade pós-industrial para sociedade da informação (WERTHEIN, 2000). Com isso, ocorreram diversas mudanças no que diz respeito à formação básica das pessoas, bem como a capacitação das mesmas para a absorção no mercado de trabalho e na compreensão do seu papel como cidadão, ou seja, no cumprimento dos deveres e busca pelos direitos em seus coletivos sociais. 


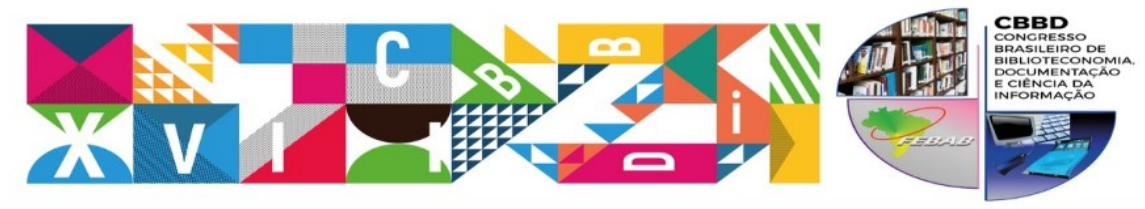

XXVII CONGRESSO BRASILEIRO DE BIBLIOTECONOMIA, DOCUMENTAÇÃO E CIÊNCIA DA INFORMAÇÃO

TEMA CENIral: Objetivos para o Desenvolvimento Sustentável das Naçōes Unidas:
como as bibliotecas podem contribuir com a implementaçāo da Agenda 2030

No que tange a formação básica das pessoas (da educação infantil ao ensino médio), escolhemos a perspectiva do Aprender a Aprender (ORGANIZAÇÃO DAS NAÇÕES UNIDAS PARA A EDUCAÇÃO, A CIÊNCIA E A CULTURA, 2008), como uma das propostas educativas que mais refletem não só com a perspectiva corporativa como também busca desenvolver a pessoa ao longo da vida, seja qual for sua necessidade de informação e aprendizado. Com isso, ao alinhar a mudança social provocada pelas TIC à perspectiva educacional do aprendizado contínuo, encontramos na Competência em Informação (CoInfo) um grande campo de trabalho para que profissionais da informação contribuam para a mudança social.

Dessa forma, será retratada a CoInfo, sobretudo sua perspectiva educacional situada no ambiente escolar, a partir da exposição, descrição e socialização das ações e dos resultados do projeto de extensão 'Competência em Informação: implementação e avaliação de um programa para o âmbito escolar'. 0 projeto foi desenvolvido por docentes e discentes dos cursos de Licenciatura e Bacharelado em Biblioteconomia da Universidade Federal do Estado do Rio de Janeiro (UNIRIO) no Colégio Pedro II (CPII), uma escola pública da cidade do Rio de Janeiro.

A CoInfo instiga uma filosofia de educação em informação bem como de educação pela informação. Insere-se em um contexto marcado pelo excesso de informações, em diferentes formatos e suportes, notadamente o contexto da Sociedade da Informação, marcada especialmente pelos constantes processos de produção e circulação de informações e pelas rápidas mudanças tecnológicas. Com efeito, este cenário demanda novas práticas de ensino e de aprendizagem.

Reconhece a CoInfo como necessária para desenvolver nas pessoas conhecimentos e habilidades no que tange o entendimento da informação, sua busca, acesso, avaliação e uso. Neste sentido, atrela-se o desenvolvimento de habilidades técnicas à missão educacional que diz respeito a formação das pessoas com vistas ao exercício pleno da cidadania. Este trabalho visa compreender a CoInfo como uma perspectiva de mudança social, uma vez que a busca, acesso, avaliação e uso críticos da informação podem romper as desigualdades que marcam as sociedades atuais por seu envolvimento básico no processo de construção e disseminação de conhecimento (LAU, 2008). 


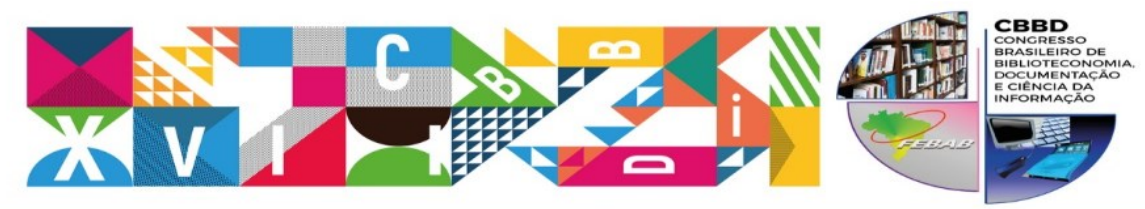

XXVII CONGRESSO BRASILEIRO DE BIBLIOTECONOMIA,

DOCUMENTAÇÃO E CIÊNCIA DA INFORMAÇÃO

TEMA CENTral: Objetivos para o Desenvolvimento Sustentável das Naçōes Unidas:
como as bibliotecas podem contribuir com a implementaçāo da Agenda 2030

No que se refere ao desenvolvimento do campo, destaca-se que, durante os anos de estudos e pesquisas sobre a CoInfo em diversos países, foram criados padrões, diretrizes e programas que envolvem a formação de pessoas em inúmeros espaços e contextos (a biblioteca em seus diferentes tipos, demais unidades de informação, escolas, universidades, empresas). Estes documentos norteiam os criadores de programas em relação às competências que podem ser desenvolvidas, as metodologias que podem ser aplicadas e os objetivos que podem ser atingidos.

Dessa forma, o projeto desenvolvido objetivou criar e implementar um programa de CoInfo em uma escola pública com alunos do ensino fundamental, neste caso o CPII que abraçou a realização desta ação de extensão universitária da UNIRIO. Assim, os objetivos deste artigo são socializar as ações desenvolvidas no âmbito deste projeto bem como apontar seus resultados. Busca também, refletir sobre as possibilidades práticas da CoInfo a partir da criação e implementação de programas desta natureza.

0 artigo divide-se em cinco seções, a saber: 1) Introdução, que aqui encerra; 2) Fundamentação Teórica para apresentar a filosofia e o desenvolvimento da CoInfo, a partir das pesquisas empreendidas sobre este tema, e destacar a existência de diretrizes, modelos e programas, estabelecidos por diferentes pesquisadores e/ou instituições, visto que estes documentos existentes servem de base para a elaboração de programas para o âmbito escolar; 3) Procedimentos Metodológicos, para apontar os métodos e técnicas utilizados no desenvolvimento do trabalho; 4) Resultados, para descrever a criação do programa e socializar os resultados de sua implementação; e 5) Explanação das considerações finais.

\section{FUNDAMENTAÇÃO TEÓRICA}

A CoInfo ${ }^{1}$, conceitualmente, sofreu diversas mudanças enquanto área de pesquisa em Biblioteconomia e Ciência da Informação. Vitorino e Piantola (2009) explicam que no

\footnotetext{
${ }^{1}$ Em 2014, durante o "III Seminário de Competência em Informação: cenários e tendências", em Marília, estado de São Paulo, em continuidade aos esforços dos I e II Seminários que culminaram com as publicações oficiais da "Declaração de Maceió" e do "Manifesto de Florianópolis", redigiu-se um documento chamado "A Carta de Marília" onde apresentaram constatações e diretrizes. Os participantes reafirmam "[...] apoio Revista Brasileira de Biblioteconomia e Documentação - v. 13, n. esp. CBBD 2017
} 


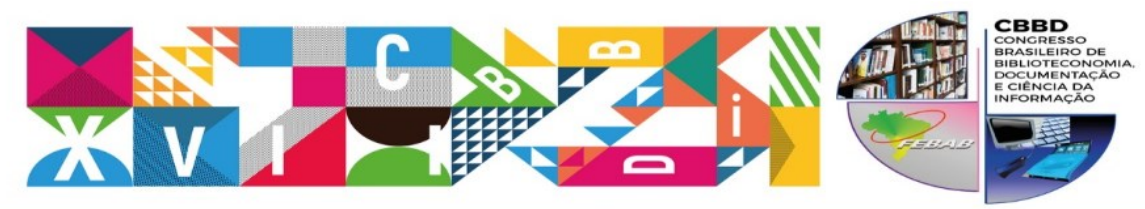

XXVII CONGRESSO BRASILEIRO DE BIBLIOTECONOMIA,

DOCUMENTAÇÃO E CIÊNCIA DA INFORMAÇÃO

TEMA CENTral: Objetivos para o Desenvolvimento Sustentável das Naçōes Unidas:
Como as bibliotecas podem contribuir com a implementaçāo da Agenda 2030

Brasil, o termo foi traduzido de information literacy surgido nos Estados Unidos da América (EUA) na década de 1970², mas com características diferentes do que se conhece atualmente.

A CoInfo começou a ser estudada em diversos países por volta da década de 1970, entretanto, no Brasil, somente nos anos 2000 começaram as primeiras pesquisas. 0 termo levantou interesse a partir do artigo "O desenvolvimento de habilidades informacionais: o papel das bibliotecas universitárias no contexto da informação digital em rede" de Sônia Caregnato (2000). A autora traduziu information literacy como alfabetização informacional e abordou a necessidade de se desenvolver habilidades informacionais para os usuários de bibliotecas interagirem no ambiente digital.

Dudziak (2003) explica que o termo está ligado ao conceito de Sociedade da Informação uma vez que, após a segunda Guerra mundial, as necessidades informacionais, sobretudo para atender as demandas mercadológicas, representaram também uma importância social devido ao desenvolvimento de novas tecnologias de informação e comunicação.

Ao longo das décadas, houve importantes avanços nas pesquisas e aplicações práticas pelo mundo. Foram criadas diretrizes e modelos de aplicação tais como o Information Search Process (ISP) de Carol Kuhlthau de 1987; o Big Six Skills de Eisenberg e Berkowitz de 1988; o Research Cycle, modelo de James Mackenzie de 1995 nos EUA; o modelo PLUS de James E. Herring de 1996 no Reino Unido; Modelo de Gávilan de 1996 na Colômbia; o modelo EXIT de Wray e Lewis de 1997 em Londres; entre outros.

0 conceito passa a permear o viés educativo no Brasil quando, em 2002, Bernadete Campello e o Grupo de Estudos em Biblioteca Escolar (GEBE) publicam um livro sobre a função educativa da biblioteca escolar (CAMPELLO et al., 2002). Em um dos capítulos, a autora aborda o assunto e traduz o termo Information literacy para Competência Informacional com o intuito de trabalhá-lo em bibliotecas escolares, pois acreditava que

incondicional à relevância da adoção da COINFO como área estratégica para o desenvolvimento social e humano e a melhoria da qualidade das organizações [...]" (CARTA..., 2014, não paginado).

2 Nos EUA, a information literacy foi utilizada pela primeira vez pelo bibliotecário americano Paul G. Zurkowski com a missão de estabelecer as diretrizes para um programa nacional de preparação e acesso universal à informação, que seria concluído até 1984 (DUDZIAK, 2010).

Revista Brasileira de Biblioteconomia e Documentação - v. 13, n. esp. CBBD 2017 

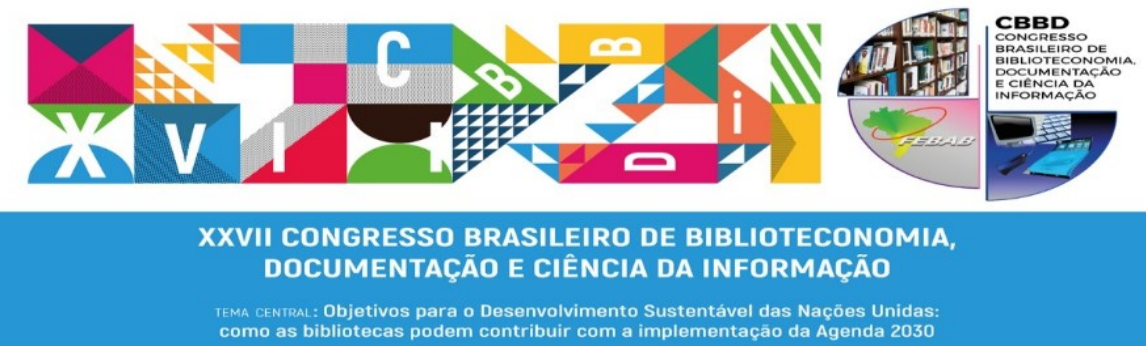

o desenvolvimento de competências em informação seria a solução para as possíveis mudanças do papel das bibliotecas para a educação do século XXI (CAMPELLO, 2002).

Apesar de muitas vezes representar uma perspectiva educacional, a CoInfo não está somente ligada ao contexto escolar. Belluzzo (2005) problematiza que a falta de aplicação e desenvolvimento das competências em informação ocasionam em problemas sociais, pois acredita que a "desinformação" atinge o homem no que deve ser sua essência: a racionalidade. Para a autora, o desenvolvimento dessas competências tem caráter inclusivo no que tange o desenvolvimento tecnológico uma vez que está voltado “[...] para a formação de cidadãos capazes de integrarem-se à era digital” (BELLUZZO, 2005, p.31). Nesta perspectiva, Belluzzo (2011) organizou as seguintes competências:

1. Definir a necessidade de informação - é necessário compreender o contexto da informação que se necessita reconhecendo o objetivo da busca;

2. Identificar e definir a informação necessária - a pessoa pode não saber exatamente a informação que precisa, daí a necessidade de refletir e analisar o que se deseja antes de buscar;

3. Saber buscar e encontrar a informação em diferentes fontes - é preciso conhecer as fontes de informação e saber utilizar as tecnologias de informação e comunicação em diversos formatos: documento impresso, eletrônico, pessoa (narrativas), organização, etc.

4. Saber analisar, interpretar, avaliar e organizar a informação relevante - é preciso selecionar as informações relevantes baseando-se na compreensão das ideias contidas, depois reformular conceitos a partir da perspectiva de quem estiver pesquisando. Também é necessário determinar se a informação adquirida é suficiente para satisfazer os objetivos da pesquisa.

5. Saber utilizar a informação para a solução de problemas - desenvolver estratégias de recuperação da informação (identificar palavras-chave, sinônimos, etc.) a fim de solucionar os problemas referentes a busca e selecionar a informação apropriada para sua pesquisa.

6. Avaliar o impacto da informação, agir eticamente e respeitar os direitos autorais

- retrata a compreensão a respeito das questões legais e éticas que envolvem a 


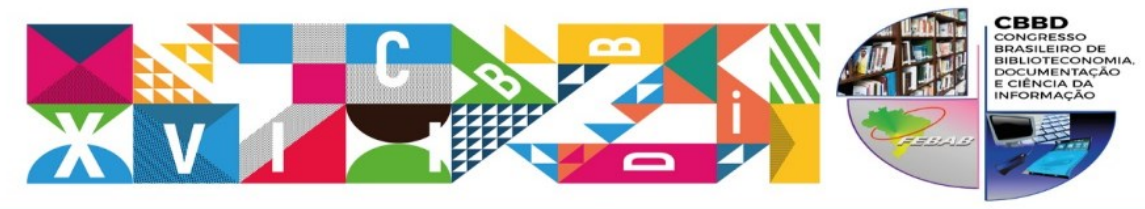

XXVII CONGRESSO BRASILEIRO DE BIBLIOTECONOMIA,

DOCUMENTAÇÃO E CIÊNCIA DA INFORMAÇÃO

TEMA CENIral: Objetivos para o Desenvolvimento Sustentável das Naçōes Unidas:
como as bibliotecas podem contribuir com a implementaçāo da Agenda 2030

informação, a comunicação e a tecnologia. Respeita a propriedade intelectual e não faz uso do plágio.

7. Sabe apresentar e comunicar a informação produzida - utiliza apropriadamente a linguagem no discurso citando corretamente todas as referências consultadas, compreende as normas de documentação recomendadas para a área de pesquisa.

8. Preserva a informação e arquiva para o futuro - agrega valor à memória cultural compreendendo a importância de se reunir, organizar, preservar e compartilhar conhecimento e informação de forma responsável.

Existem dois documentos relevantes para o desenvolvimento da CoInfo: o Manifesto da IFLA (LAU, 2008) intitulado "Diretrizes sobre o desenvolvimento de habilidades em informação para a aprendizagem permanente" e o Manifesto "Towards Information Literacy Indicators" (2008) da Organização das Nações Unidas para a Educação, a Ciência e a Cultura (UNESCO).

O documento da IFLA foi elaborado com o objetivo de ajudar "aos profissionais da informação que trabalham em programas educativos de educação fundamental e educação superior em seus esforços para atender aos requisitos de habilidades em informação na atualidade" (LAU, 2008, p. 1).

As diretrizes da IFLA são baseadas em três pressupostos: acesso, uso, avaliação.

a) Acesso - o usuário acessa a informação de forma eficaz e eficiente, isto engloba, reconhecer as necessidades de informação, iniciar o processo de busca e localizar a informação, reconhecendo as fontes e elaborando estratégias de busca; b) Avaliação - o usuário avalia a informação de maneira crítica e competente, esta etapa contempla a avaliação da informação na qual extrai a informação, analisa sua relevância, seleciona e sintetiza a informação e a organiza de forma a elencar a melhor e mais útil para a pesquisa; c) Uso - o usuário aplica/usa a informação de maneira precisa e criativa para isto, aplica a informação recuperada apreendendo o conhecimento da pesquisa realizada, depois comunica o que foi aprendido de forma ética respeitando o uso legal da informação de forma que as informações obtidas sejam referenciadas em respeito à propriedade intelectual de outros. 


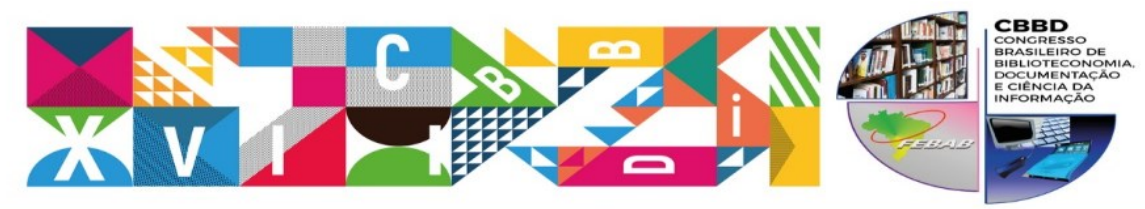

XXVII CONGRESSO BRASILEIRO DE BIBLIOTECONOMIA, DOCUMENTAÇÃO E CIÊNCIA DA INFORMAÇÃO

TEMA CENTraL: Objetivos para o Desenvolvimento Sustentável das Naçōes Unidas:
como as bibliotecas podem contribuir com a implementaçâo da Agenda 2030

O manifesto da UNESCO (2008, tradução nossa) apresenta diretrizes para o ensino superior, entretanto, menciona que também podem ser utilizados em todos os níveis:

1. Reconhecer a necessidade de informação - A consciência de que a informação é necessária para resolver problemas no local de trabalho, para entender as necessidades cívicas, e prever a saúde e bem-estar da família e da comunidade deve ser despertada, esta etapa é também o primeiro passo na diferenciação da recepção passiva da informação dada.

2. Localizar e avaliar a qualidade da informação - As habilidades necessárias para localizar informações dependem do contexto em que uma pessoa aplicará as suas habilidades de busca. Em local de trabalho, a informação pode ser localizada nos manuais, em códigos publicados, ou em bancos de dados. Nestas circunstâncias, geralmente há alguma garantia da qualidade da fonte de informação. No entanto, as pessoas procuram cada vez mais informações utilizando motores de busca da Internet muitas vezes onde não existe filtro na qualidade das informações localizadas. Educação e formação são necessárias para ajudar as pessoas a adquirem as habilidades para não apenas localizar, mas também para avaliar as fontes de informação.

3. Armazenar e recuperar informações - As pessoas sempre se preocupam com o armazenamento de informação e sua recuperação para uso posterior. Por isso, é importante desenvolver esta habilidade.

4. Fazer uso eficaz e ético da informação - A eficácia do uso da informação é suscetível de ser incluída no processo de resolução de problemas por meio do pensamento crítico. A consciência da dimensão ética da informação pode não ser bem documentada nos documentos já existentes sobre competência em informação.

5. Comunicar conhecimento - $O$ objetivo da competência em informação é capacitar as pessoas para criar novas informações e por isso, utiliza novos conhecimentos apreendidos, sintetiza-os e os comunica, representando desta forma, o produto de sua prática.

Nas diretrizes acima, foi mencionado sobre a dimensão ética da competência em informação, além desta dimensão, existem outras três que refletem estas abordagens. 

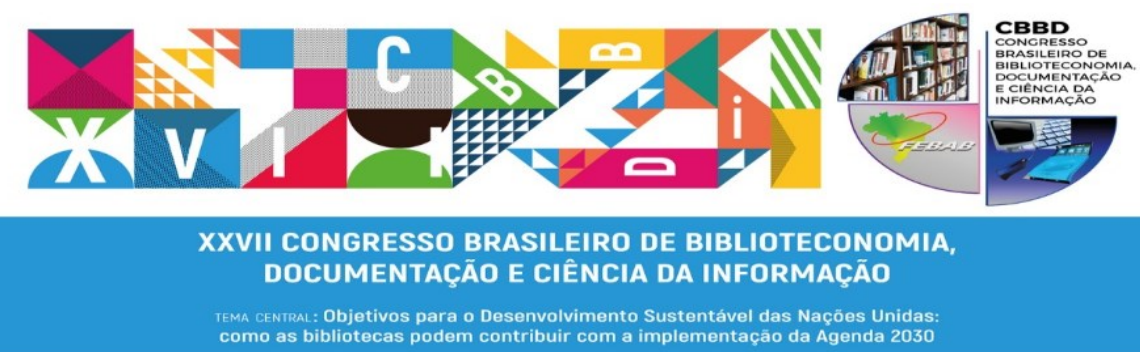

Para Vitorino e Piantola (2011) as dimensões contemplam as faces da competência em informação: a) Dimensão técnica - pode ser entendida como uma habilidade para executar uma ação, pois consiste na resolução de um problema. b) Dimensão estética está relacionada ao estudo filosófico da competência em informação, por meio da arte, ordena a dimensão das percepções pessoais, pois acredita-se que é através da sensibilidade e criatividade demandadas da arte que o homem busca atingir harmonia para o bem viver. c) Dimensão ética - esta dimensão está relacionada a noção de autonomia difundida pela competência em informação, pois acredita-se que a pessoa ética decide por si mesma e pondera suas ações para o bem coletivo. d) Dimensão política valoriza o exercício da cidadania, pois pretende desenvolver a participação das pessoas nas transformações da vida em sociedade, considera a participação pedagógica de transformar homens em cidadãos e que a informação deve ser consumida a partir de um contexto político.

Figura 1 - Documentos norteadores para formação e desenvolvimento da Competência em Informação

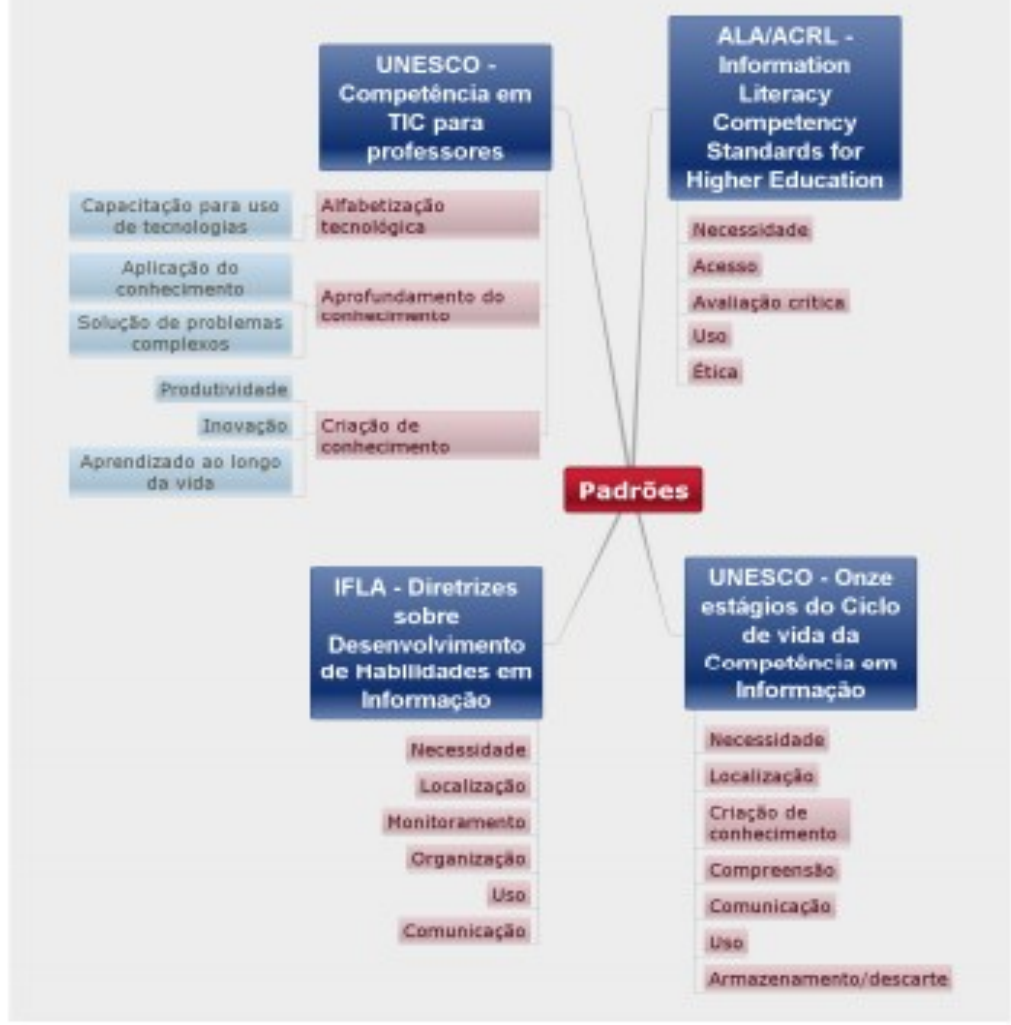

Fonte: Furtado e Alcará (2015, p.12). 


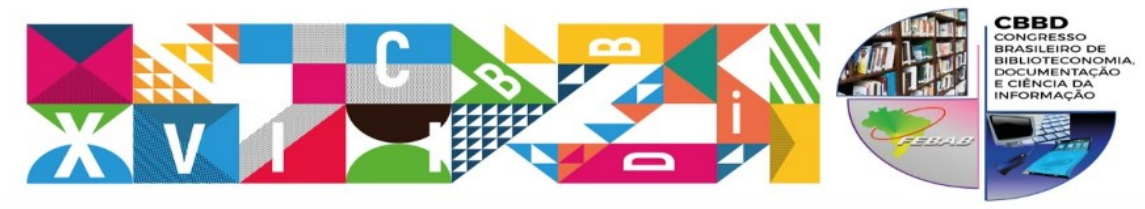

XXVII CONGRESSO BRASILEIRO DE BIBLIOTECONOMIA,

DOCUMENTAÇÃO E CIÊNCIA DA INFORMAÇÃO

TEMA CENIral: Objetivos para o Desenvolvimento Sustentável das Naçōes Unidas:
como as bibliotecas podem contribuir com a implementaçăo da Agenda 2030

Além desses documentos norteadores da American Library Association (ALA), IFLA e UNESCO diagramados na figura 1, é importante apontar na literatura, a partir de 2012, a existência de alguns programas voltados para o desenvolvimento da competência em informação como o de Durban Roca, Prolongo, García Guerrero (2012), Alves e Alcará (2014), Uribe Tirado (2014), Pereira (2015), Spudeit (2016), Martins, Bracchi, Segnorelli (2016), Martins, Moraes e Paula (2016) que apresentam as etapas, ações, público-alvo, metodologias, estratégias, entre outras informações pertinentes.

Em sites de bibliotecas, sobretudo nas universitárias, é possível perceber a criação de programas e setores voltados para essa finalidade como é o caso da Biblioteca da Universidade de Campinas ${ }^{3}$ e também na Biblioteca Central da Universidade Federal de Santa Catarina ${ }^{4}$.

Com base nas diretrizes, dimensões e programas supracitados e os objetivos elencados em relação ao projeto de CoInfo atrelado a UNIRIO, procedeu-se a elaboração e execução do programa no CPII, conforme as próximas seções.

\section{PROCEDIMENTOS METODOLÓGICOS}

Caracteriza-se como um estudo de caso na instituição pública Colégio Pedro II para a implementação do projeto "Competência em Informação: implementação e avaliação de um programa para o âmbito escolar", atrelado aos cursos de licenciatura e bacharelado em Biblioteconomia da Escola de Biblioteconomia da UNIRIO em 2015.

Trata-se de uma pesquisa descritiva, bibliográfica e documental, pois para realizar o projeto foi feito um amplo levantamento bibliográfico em literaturas especializadas da área e documentos que norteiam as bibliotecas escolares e a competência em informação em nível internacional.

\footnotetext{
3 Disponível em http://www.sbu.unicamp.br/portal2/programa-de-competencia-em-informacao/

${ }^{4}$ Disponível em http://portal.bu.ufsc.br/conheca-a-bu/administrativo/estruturaorganizacional/dau/servico-de-referencia/
}

Revista Brasileira de Biblioteconomia e Documentação - v. 13, n. esp. CBBD 2017 


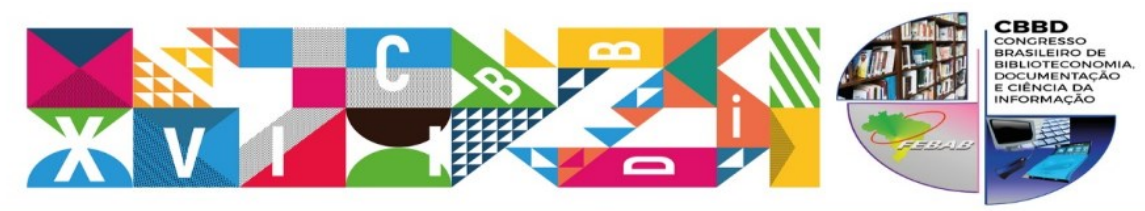

XXVII CONGRESSO BRASILEIRO DE BIBLIOTECONOMIA, DOCUMENTAÇÃO E CIÊNCIA DA INFORMAÇĀO

TEMA CENRPA: Objetivos para o Desenvolvimento Sustentável das Naçōes Unidas:
como as bibliotecas podem contribuir com a implementaça da Agenda 2030

A pesquisa bibliográfica foi feita em bases de dados como SCIELO e BRAPCI para recuperar artigos publicados em revistas científicas da área no período de 2000 a 2015. Também foram usados livros publicados sobre as temáticas no Brasil.

A partir disso, foi organizado em maio de 2015 o I Fórum sobre Competência em Informação: pesquisas e práticas na cidade do Rio de Janeiro numa parceria entre os cursos de Biblioteconomia da UNIRIO e da Universidade Federal do Rio de Janeiro (UFRJ) para divulgar relatos de experiências e pesquisas sobre a temática.

Também foi possível conhecer vários documentos norteadores sobre a Competência em Informação que subsidiaram a criação, implementação e avaliação de um programa de competência em informação para ser aplicado em uma escola pública no Rio de Janeiro conforme relato a seguir.

\section{RESULTADOS}

O objetivo geral do projeto foi criar um programa de desenvolvimento de competências em informação no âmbito escolar. Para tanto, foram traçados os seguintes objetivos específicos: a) mapear e analisar os programas de competência de informação existentes na literatura; b) construir um programa que vise o desenvolvimento de competências em informação no âmbito escolar; c) implementar o programa em uma escola pública na cidade do Rio de Janeiro; e d) avaliar o programa para verificar a eficácia e eficiência do mesmo. Por meio de uma pesquisa bibliográfica foi feito um levantamento de dados para atender ao primeiro e segundo objetivo para criar um programa de desenvolvimento de competência em informação para aplicação prática em alunos do ensino fundamental de rede pública da cidade do Rio de Janeiro conforme quadro 1: 


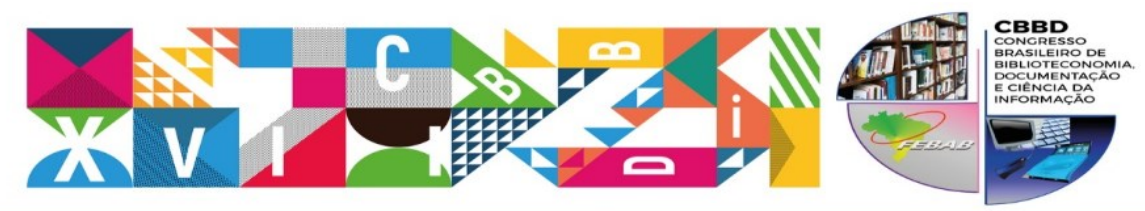

XXVII CONGRESSO BRASILEIRO DE BIBLIOTECONOMIA,

DOCUMENTAÇÃO E CIÊNCIA DA INFORMAÇÃO

TEMA CENTral: Objetivos para o Desenvolvimento Sustentável das Naçōes Unidas:
como as bibliotecas podem contribuir com a implementaçăo da Agenda 2030

Quadro 1 - Etapas do projeto

\begin{tabular}{|c|c|c|}
\hline Etapa & Ação & Carga horária \\
\hline \multirow{5}{*}{1 Planejamento } & Levantamento bibliográfico e estudo sobre o tema & 80 horas \\
\hline & Preparação do material & 30 horas \\
\hline & Organização da metodologia do programa & 30 horas \\
\hline & Contatos e seleção da instituição & 10 horas \\
\hline & $\begin{array}{l}\text { Organização do programa e reuniões com professores } \\
\text { da instituição }\end{array}$ & 30 horas \\
\hline 2 Execução & $\begin{array}{l}\text { Realização das ações previstas no programa na } \\
\text { instituição selecionada }\end{array}$ & 40 horas \\
\hline 3 Avaliação & $\begin{array}{l}\text { Avaliação do projeto, do programa e redação do } \\
\text { relatório final }\end{array}$ & 20 horas \\
\hline \multicolumn{2}{|r|}{ Carga horária total } & 240 horas \\
\hline
\end{tabular}

Fonte: elaborado pelos autores (2017).

Na etapa de planejamento, buscou-se nas bases de dados SCIELO e BRAPCI diferentes textos, artigos, dissertações, teses sobre a temática para aprofundar o estudo sobre o tema que ocupou 80 horas da carga horária. A partir dessa seleção, houve leituras e discussões dos textos entre integrantes do projeto para aprofundamento e esclarecimento de dúvidas. Nesta mesma etapa, realizou-se o primeiro objetivo que foi o mapeamento dos programas existentes acessíveis na íntegra e selecionou-se os programas de Durban Roca, Prolongo, García Guerrero (2012), Alves e Alcará (2014), Uribe Tirado (2014), Pereira (2015). Com base nesses autores supracitados é que se iniciou o segundo objetivo para construir um rascunho (esqueleto) de um programa de CoInfo voltado para âmbito escolar.

Foi feito contato com várias escolas públicas que tivessem biblioteca e bibliotecário no Rio de Janeiro. Após vários alinhamentos, a escola escolhida foi o Colégio Pedro II Campus Humaitá. Conforme o quadro 1, houve reuniões de planejamento com equipe da biblioteca, professores e coordenação pedagógica da instituição para concretização da parceria. Foi escolhida pela escola uma turma do $6^{0}$ ano vespertino, que tinha em torno de 25 alunos, para aplicação do projeto.

Junto à equipe da UNIRIO e do CPII, foi finalizado o programa pautado no Projeto Pedagógico da instituição e organizados os encontros com a turma. 0 tema escolhido pela escola foi Olimpíadas e assim o programa foi organizado em seis etapas. Em cada uma das etapas, foi planejada uma atividade para desenvolver as competências alinhadas aos 


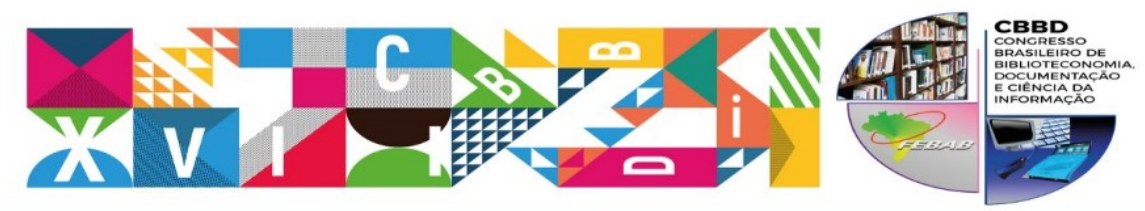

XXVII CONGRESSO BRASILEIRO DE BIBLIOTECONOMIA, DOCUMENTAÇÃO E CIÊNCIA DA INFORMAÇÃO

TEMA CENTral: Objetivos para o Desenvolvimento Sustentável das Naçōes Unidas:
como as bibliotecas podem contribuir com a implementaçăo da Agenda 2030

objetivos específicos do programa apropriados para a faixa etária dos participantes e necessidades dos mesmos. Em cada etapa houve a participação de um professor de diferentes disciplinas do $6^{\circ}$ ano. As atividades foram realizadas em variados ambientes e espaços de aprendizagem da escola, tais como biblioteca, laboratório de informática, auditório, entre outros.

Como pressupostos teóricos, o programa foi estruturado com base nas diretrizes da SCONUL/AACRL, CAUL, ANZIIL, AASL, IFLA, UNESCO onde se analisou o que tinha em comum entre elas e destacamos abaixo alguns parâmetros que nortearam as ações do programa. Nas atividades é importante que o aluno desenvolva competências para:

a) reconhecer a necessidade de informação (gap) e determinar a natureza e extensão do que precisa;

b) acessar a informação de forma eficaz e eficiência usando estratégias de busca (seja em meio impresso ou digital);

c) avaliar a qualidade da informação encontrada, comparar e analisar para selecionar o que será usado;

d) organizar, classificar, armazenar e recuperar essas informações para serem usadas depois;

e) usar a informação de forma precisa, criativa e ética;

f) expandir seu conhecimento prévio para articular com as novas informações encontradas;

g) sintetizar, criar, comunicar para gerar novos conhecimentos e socializar aquilo que aprendeu.

Para elaborar as ações do programa usamos como base a obra "Como usar a biblioteca na escola: um programa de atividades para o ensino fundamental", o livro "Processos de Ensinagem na Universidade: pressupostos para as estratégias de trabalho em aula" (ANASTASIOU; ALVES, 2012) e também alguns programas existentes na literatura, tais como Information Search Process criado em 1981 por Karol Kulthau, o Big Six Skills criado em 1988 pelos americanos Eisenberg e Berkowitz, o The Research Cycle criado em 1995 pelo professor Jamie Mackenzie, o Programa PLUS criado em 1996 pelo professor James Hering no Reino Unido, o Flip It desenvolvido pela educadora Alice H. 


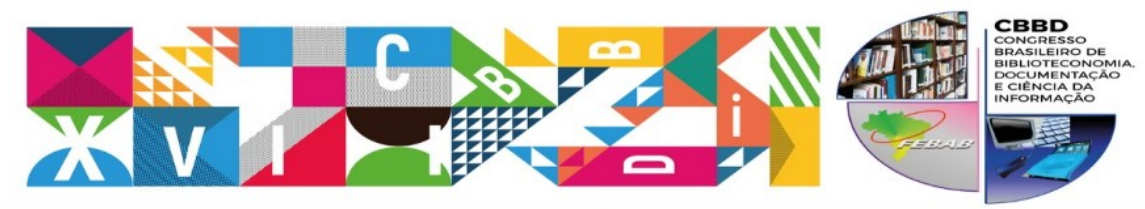

XXVII CONGRESSO BRASILEIRO DE BIBLIOTECONOMIA,

DOCUMENTAÇÃO E CIÊNCIA DA INFORMAÇÃO

TEMA CENTraL: Objetivos para o Desenvolvimento Sustentável das Naçōes Unidas:
como as bibliotecas podem contribuir com a implementaçăo da Agenda 2030

Yucht em meados de 1988, o 8Ws of Information Inquiry desenvolvido por Annette Lam e, por último, o Programa de Letramento criado pela brasileira Kelley Gasque.

As ações foram adequadas de acordo com o projeto pedagógico, missão, contexto, interesses e necessidades da instituição e do grupo envolvido no qual foi priorizada a participação e colaboração efetiva da equipe da biblioteca e dos diferentes professores que ministram disciplinas para o 6.ano do Colégio Pedro II para que a proposta seja interdisciplinar e possa valorizar os conhecimentos e experiências prévios dos participantes e seus interesses como fonte de aprendizagem significativa. Isso se alinha ao projeto pedagógico do Colégio Pedro II (2002, p. 65) onde enfatiza:

A escola deve estar voltada para a formação de um ser humano crítico e autocrítico, pautado em princípios éticos, de valorização da dignidade e dos direitos humanos, bem como de respeito às diferenças individuais e socioculturais, capaz de mobilizar-se por aspirações justas visando ao bem comum. Em outras palavras, a constituição de identidades autônomas, sujeitos em situação, dotados de competências e de valores: cidadãos. Consciente de seu papel, a escola tem uma contribuição decisiva a dar no processo de construção da cidadania, acreditando que a atuação solidária de pessoas autônomas pode levar à melhoria da sociedade.

Como se percebe a instituição escolhida para implantação do programa tem essa preocupação na formação de pessoas críticas, reflexivos e éticos indo ao encontro do que é proposto pela UNIRIO ao desenvolver competência em informação nos alunos do 6ํㅡㅁ ano.

A escola, preocupada com a construção do conhecimento e com a formação de valores considera o conhecimento já possuído do aluno, seu interesse e vontade em conhecer e descobrir por meio de situações desafiadoras e significativas, desenvolver capacidade crítica e de reflexão de forma interativa e dinâmica (COLÉGIO PEDRO II, 2002, p. 69).

$\mathrm{Na}$ fase de execução, o programa foi dividido em seis etapas, em seis dias sendo um por semana. Cada etapa teve três horas por dia o que totalizou 18 horas para execução do programa em si dentro da escola, porém essa etapa de execução ao todo teve duração de 40 horas, pois havia o planejamento de cada ação.

O programa elaborado contém a descrição da instituição, público-alvo, objetivo geral e específico, descrição das atividades, recursos, resultados esperados, avaliação 


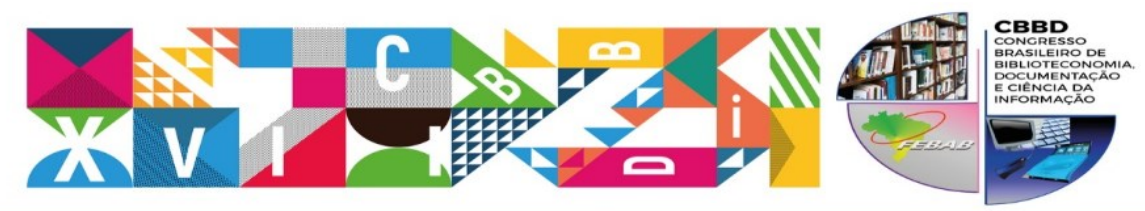

XXVII CONGRESSO BRASILEIRO DE BIBLIOTECONOMIA,

DOCUMENTAÇÃO E CIÊNCIA DA INFORMAÇÃO

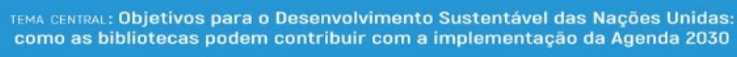

conforme quadro exposto a seguir:

Quadro 2 - Programa de competência em informação para Colégio Pedro II

\begin{tabular}{|c|c|}
\hline Local para aplicação & Colégio Pedro II - Campus Humaitá II (Rio de Janeiro RJ) \\
\hline Caracterização do local & $\begin{array}{l}\text { Instituição pública de ensino da Rede Federal de Educação } \\
\text { Profissional, Científica e Tecnológica fundada em } 02 \text { de dezembro de } 1837 \text {, } \\
\text { localizada no Rio de Janeiro, autarquia do MEC que tem como missão } \\
\text { ministrar ensino público e gratuito nos níveis fundamental e médio de } \\
\text { acordo com projeto político pedagógico (COLÉGIO PEDRO II, 2002, p. } \\
\text { 29). Na unidade escolhida tem turmas do ensino fundamental (séries finais) } \\
\text { e ensino médio que funcionam nos períodos matutino, vespertino e noturno. } \\
\text { De acordo com projeto pedagógico do Colégio Pedro II (2002, p. 70), } \\
\text { destaca-se algumas competências transdisciplinares que a escola pretende } \\
\text { desenvolver nos alunos e que estão alinhadas ao programa de competência } \\
\text { em informação a ser implementado pela UNIRIO: } \\
\text { - Ler e interpretar diferentes tipos de discurso e de texto; } \\
\text { - Produzir textos orais e escritos com organização lógica e } \\
\text { consistente; } \\
\text { - Analisar a intervenção das tecnologias nos processos de produção } \\
\text { e reprodução do conhecimento; } \\
\text { Traduzir os conhecimentos em condutas de indagação, análise } \\
\text { crítica, problematização e intervenção em situações, problemas ou } \\
\text { questões da prática social; } \\
\text { Mobilizar informações, conceitos e conhecimentos para construir } \\
\text { argumentação consistente em defesa de pontos de vista e de } \\
\text { tomadas de decisão na vida cidadã. }\end{array}$ \\
\hline Público-alvo & Alunos do $6^{\circ}$ ano do ensino fundamental. \\
\hline $\begin{array}{l}\text { Quantidade de pessoas } \\
\text { favorecidas }\end{array}$ & 25 alunos do $6^{\circ}$ ano vespertino. \\
\hline $\begin{array}{l}\text { Objetivo geral do } \\
\text { programa }\end{array}$ & $\begin{array}{l}\text { Desenvolver competência para formar cidadãos críticos e autônomos } \\
\text { capazes de interferir construtivamente na sociedade. }\end{array}$ \\
\hline $\begin{array}{l}\text { Objetivos específicos das } \\
\text { atividades }\end{array}$ & $\begin{array}{l}\text { - Identificar as necessidades informacionais. } \\
\text { Empregar estratégias e técnicas para encontrar e organizar a } \\
\text { informação, de modo a localizar as mais importantes a fim de } \\
\text { resolver um determinado problema verificado a partir de uma } \\
\text { necessidade de informação. } \\
\text { - Aplicar critérios que permitam avaliar se a informação obtida é } \\
\text { confiável e sua qualidade e selecionar as informaçoes. } \\
\text { - Identificar e selecionar as ideias principais por meio da leitura e } \\
\text { análise de textos } \\
\text { Destacar e apresentar as ideias principais de um documento de } \\
\text { forma estruturada e organizada, devendo simplificar e demonstrar } \\
\text { compreensão do conteúdo do texto através da esquematização e } \\
\text { do resumo. } \\
\text { Gerar novos conhecimentos a partir da escrita, citação e } \\
\text { apresentação das ideias. }\end{array}$ \\
\hline Duração & O programa será executado em seis etapas, dividido em seis dias sendo um \\
\hline
\end{tabular}




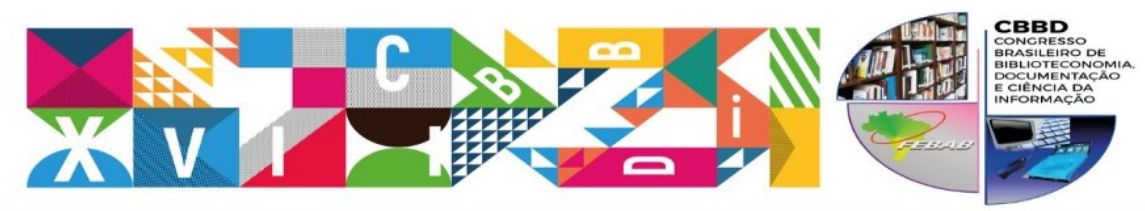

\begin{tabular}{|c|c|}
\hline & $\begin{array}{l}\text { por semana. Cada etapa terá três horas por dia o que totalizará } 18 \text { horas } \\
\text { para execução do programa na instituição e } 22 \text { horas para o planejamento } \\
\text { de cada atividade. }\end{array}$ \\
\hline Descrição do programa & $\begin{array}{l}\text { O tema escolhido pela escola foi Olimpíadas } 2016 \text { e assim organizamos o } \\
\text { programa em seis etapas. Em cada uma das etapas, foi planejada uma } \\
\text { atividade para desenvolver as competências alinhadas aos objetivos } \\
\text { específicos do programa apropriados para a faixa etária dos participantes e } \\
\text { necessidades dos mesmos. Em cada etapa haverá a participação de um } \\
\text { professor de diferentes disciplinas do } 6 \text {. Ano. As atividades serão } \\
\text { realizadas em variados ambientes e espaços de aprendizagem da escola, } \\
\text { tais como biblioteca, laboratório de informática, auditório, entre outros } \\
\text { conforme descrição no anexo A. }\end{array}$ \\
\hline Recursos & $\begin{array}{l}\text { Biblioteca (livros, revistas, mesa, cadeiras), laboratório de informática } \\
\text { (computadores, impressora), serviço de fotocópia, sala de aula (mesas, } \\
\text { cadeiras, quadro), quadra, professores, bibliotecários, voluntários. }\end{array}$ \\
\hline Resultados esperados & $\begin{array}{l}\text { Espera-se que após a conclusão das atividades, os alunos consigam } \\
\text { identificar as necessidades informacionais, empregar estratégias e técnicas } \\
\text { para encontrar e organizar a informação, de modo a localizar as mais } \\
\text { importantes a fim de resolver um determinado problema verificado a partir } \\
\text { de uma necessidade de informação, aplicar critérios que permitam avaliar } \\
\text { se a informação obtida é confiável e sua qualidade e selecionar as } \\
\text { informações, identificar e selecionar as ideias principais através da leitura e } \\
\text { análise de textos, destacar e apresentar as ideias principais de um } \\
\text { documento de forma estruturada e organizada, devendo simplificar e } \\
\text { demonstrar compreensão do conteúdo do texto através da esquematização e } \\
\text { do resumo, gerar novos conhecimentos a partir da escrita, citação e } \\
\text { apresentação das ideias. }\end{array}$ \\
\hline
\end{tabular}

Fonte: elaborado pelos autores (2017).

As ações a serem apresentadas no quadro a seguir foram organizadas pensando no objetivo do Colégio Pedro II (2002, p. 70): “formar cidadãos críticos, eticamente orientados para o respeito às identidades, politicamente comprometidos com a igualdade, dotados de competências e de valores capazes de mobilizá-los para a intervenção responsável na sociedade".

A descrição das atividades foi adaptada do quadro exposto por Mata (2009) conforme quadro a seguir.

Quadro 3 - Descrição das atividades realizadas no Programa de COINFO no Colégio Pedro II

\begin{tabular}{|c|l|c|}
\hline $\begin{array}{c}\text { Habilidades/ } \\
\text { Conhecimentos/ } \\
\text { Atitudes }\end{array}$ & \multicolumn{1}{|c|}{ Descrição } & Atividades (elaboradas pela equipe) \\
\hline $\begin{array}{c}\text { Identificação } \\
\text { das }\end{array}$ & $\begin{array}{l}\text { Consiste em entender se uma informação é } \\
\text { necessária, o motivo pelo qual o é, qual o o } \\
\text { formato/suporte da informação desejada, }\end{array}$ & $\begin{array}{l}\text { Conversa expositiva-dialogada e realização de } \\
\text { brainstorming. Houve explicação sobre os } \\
\text { tipos de fontes de acordo com o conhecimento }\end{array}$ \\
\hline
\end{tabular}




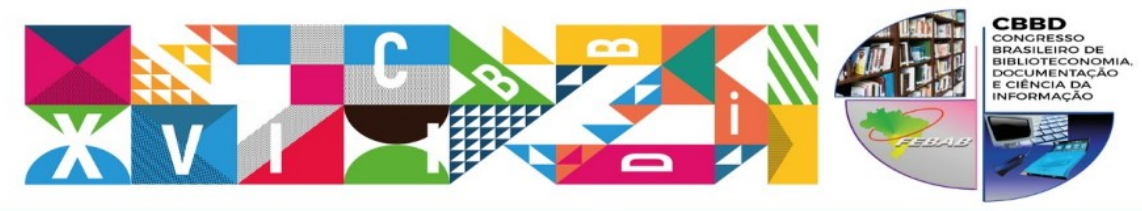

XXVII CONGRESSO BRASILEIRO DE BIBLIOTECONOMIA,

DOCUMENTAÇÃO E CIÊNCIA DA INFORMAÇÃO

TEMA CENTral: Objetivos para o Desenvolvimento Sustentável das Naçōes Unidas:
como as bibliotecas podem contribuir com a implementaçăo da Agenda 2030

\begin{tabular}{|c|c|c|}
\hline $\begin{array}{c}\text { necessidades } \\
\text { informacionais }\end{array}$ & $\begin{array}{l}\text { se está em um canal formal ou informal, } \\
\text { em fontes primárias, secundárias ou } \\
\text { terciárias, deve-se definir idioma, o nível } \\
\text { científico, os tipos de documentos; o } \\
\text { período de cobertura; o grau de precisão ou } \\
\text { exaustividade. }\end{array}$ & $\begin{array}{l}\text { prévio deles. Depois a turma foi separada em } \\
\text { grupos, foram elaboradas questões problemas } \\
\text { sobre o tema e realizado o Quizz com placas } \\
\text { V ou F. }\end{array}$ \\
\hline $\begin{array}{l}\text { Busca da } \\
\text { informação }\end{array}$ & $\begin{array}{l}\text { Implica em obter um conjunto de } \\
\text { informações e documentos necessários } \\
\text { para resolver um determinado problema } \\
\text { por meio do uso de estratégias e técnicas } \\
\text { para encontrar e organizar a informação. } \\
\text { Envolve a seleção de ferramentas de } \\
\text { busca, escolha de conceitos de consulta } \\
\text { (tradução do termo da linguagem natural } \\
\text { para uma linguagem documentária), uso } \\
\text { de operadores booleanos, cobertura } \\
\text { temática e geográfica, idioma; etc. }\end{array}$ & $\begin{array}{l}\text { Jogo de caça ao tesouro na biblioteca } \\
\text { (primeiro mostrar como a biblioteca está } \\
\text { organizada e como buscar as informações) e } \\
\text { no laboratório de informática (em grupos com } \\
\text { monitores). Foram elaboradas regras e } \\
\text { dinâmica do jogo que envolviam ferramentas } \\
\text { de busca, manuseio de diferentes fontes, etc. } \\
\text { A equipe que achava a resposta em fonte } \\
\text { (impressa ou digital) ganhava outra pista até } \\
\text { chegar ao final e ser vencedora. }\end{array}$ \\
\hline $\begin{array}{l}\text { Avaliação da } \\
\text { informação }\end{array}$ & $\begin{array}{l}\text { Pauta-se na avaliação dos conteúdos } \\
\text { recuperados com base em critérios tais } \\
\text { como veracidade, a credibilidade, a } \\
\text { confiabilidade e a qualidade da } \\
\text { informação bem como a autoridade. }\end{array}$ & $\begin{array}{l}\text { Júri simulado com análise comparativa de } \\
\text { fontes em grupo. A turma foi dividida em três } \\
\text { grupos (acusação, defesa e jurados) para } \\
\text { julgar se uma determinada situação problema. } \\
\text { Os grupos deveriam fundamentar suas } \\
\text { estratégias de acusação e defesa com fontes de } \\
\text { informações confiáveis de acordo com os } \\
\text { critérios expostos na aula que antecedeu a } \\
\text { atividade. }\end{array}$ \\
\hline $\begin{array}{c}\text { Análise e síntese } \\
\text { da informação }\end{array}$ & $\begin{array}{l}\text { Esse processo implica o reconhecimento } \\
\text { da informação através da leitura e análise } \\
\text { de textos para identificar as ideias } \\
\text { principais, exame do texto em pequenas } \\
\text { partes para facilitar a compreensão, } \\
\text { representação e aprendizagem, } \\
\text { entendimento do significado da } \\
\text { informação para poder escrevê-la, } \\
\text { esquematizá-la, organizá-la, interpretá-la, } \\
\text { hierarquizá-la, relacioná-la e expô-la. } \\
\text { Pode ser feito em forma de resumo, } \\
\text { esquemas como mapas conceituais, } \\
\text { diagramas, etc. }\end{array}$ & $\begin{array}{l}\text { Roda de leitura no pátio e depois a oficina em } \\
\text { sala de aula com textos pré-selecionados } \\
\text { (individual) para aprender a extrair palavras- } \\
\text { chaves, elaborar resumo e fichamento do texto } \\
\text { com base em citações. Teve também uma } \\
\text { oficina sobre normas da ABNT e orientações } \\
\text { sobre como evitar plágio bem como as } \\
\text { implicações éticas que permeiam as condutas } \\
\text { do discente que plagia. }\end{array}$ \\
\hline $\begin{array}{l}\text { ender a } \\
\text { unicar }\end{array}$ & $\begin{array}{l}\text { A partir da assimilação de novos conceitos } \\
\text { e estruturação da informação, a } \\
\text { comunicação (oral e escrita) é a atividade } \\
\text { que culmina no processo de aprendizagem } \\
\text { e na geração de novos conhecimentos. } \\
\text { Para comunicar, a pessoa deverá aprender } \\
\text { algumas técnicas de redação e citação para } \\
\text { desenvolver uma ideia central com } \\
\text { argumentos, capacidade crítica e uma } \\
\text { conclusão do que se pretende comunicar. }\end{array}$ & $\begin{array}{l}\text { Troca das sínteses entre os alunos para criação } \\
\text { de um texto colaborativo por grupo e criação } \\
\text { de um produto com base nas pesquisas e } \\
\text { atividades realizadas ao longo do projeto para } \\
\text { que seja apresentado para a turma (em grupo) } \\
\text { que poderá ser em forma de encenação, vídeo, } \\
\text { música e também o registro no blog (era } \\
\text { opcional). }\end{array}$ \\
\hline ender & $\begin{array}{l}\text { Consiste em compreender como se } \\
\text { desenvolve a capacidade de conhecimento } \\
\text { e aprendizagem, como se forma conceitos }\end{array}$ & $\begin{array}{l}\text { Exposição de todos os trabalhos feitos na } \\
\text { escola (troca de ideias, avaliação do projeto e } \\
\text { da atividade dos alunos da escola, dos }\end{array}$ \\
\hline
\end{tabular}




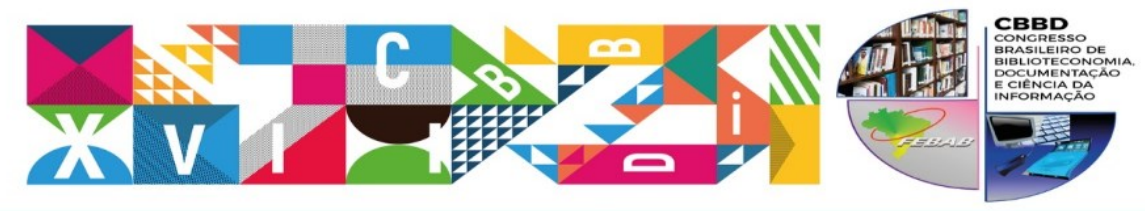

XXVII CONGRESSO BRASILEIRO DE BIBLIOTECONOMIA, DOCUMENTAÇÃO E CIÊNCIA DA INFORMAÇÃO

TEMA CENTRaL : Objetivos para o Desenvolvimento Sustentável das Naçōes Unidas:
como as bibliotecas podem contribuir com a implementaçâo da Agenda 2030

\begin{tabular}{|l|l|l|}
\hline & $\begin{array}{l}\text { de uma maneira significativa e autônoma, } \\
\text { como se memoriza a informação, como se } \\
\text { define objetivos e se busca a informação } \\
\text { em fontes e recursos avaliados e e e } \\
\text { confiáveis. }\end{array}$ & $\begin{array}{l}\text { bolsistas e voluntários envolvidos) para } \\
\text { socialização do projeto para a comunidade } \\
\text { preservão), ocorreu também uma } \\
\text { divulgação dos resultados do projeto no site da } \\
\text { instituição. }\end{array}$ \\
\hline
\end{tabular}

Fonte: elaborado pelos autores (2017).

A última fase do projeto envolvia a avaliação do projeto e também do programa em si. A equipe da UNIRIO foi avaliada pelos professores por meio de um formulário de observação, assim como os próprios alunos puderam se auto avaliar e também avaliaram o projeto de extensão ao final do mesmo. Quanto a avaliação da aprendizagem dos alunos do 6ํano do Colégio Pedro II não foi possível ocorrer porque o colégio entrou em greve juntamente com as demais universidades federais do Rio de Janeiro. Nesse sentido, houve apenas registros dos próprios alunos da UNIRIO, participantes do projeto, em seus diários de bordo e também em observações feitas ao longo do processo que possibilitaram os ajustes e melhorias no decorrer da implementação do projeto no Colégio Pedro II.

Os alunos, profissionais e demais participantes do Colégio Pedro II preencheram uma ficha de avaliação ao final do curso para verificar se os objetivos das atividades foram atingidos, porém teve pouco retorno pois havia iniciado a greve, mas foi possível perceber o alcance dos objetivos.

Os critérios de avaliação que constaram no formulário foram criados pelos próprios participantes do projeto da UNIRIO e contemplavam critérios atitudinais como pontualidade, comprometimento, respeito, dedicação, iniciativa, colaboração, entre outros, e também critérios relacionados às habilidades e ao conhecimento construídos ao longo do desenvolvimento do projeto, tanto no planejamento quanto na execução do mesmo.

\section{CONSIDERAÇÕES}

O projeto conseguiu atingir os objetivos propostos, embora com dificuldades em sua implementação. A fase de planejamento transcorreu de acordo como o previsto, com encontros regulares do grupo na UNIRIO para estudos e debates sobre CoInfo e a realização de um evento numa parceria entre a UNIRIO e a UFRJ intitulado I Fórum sobre 


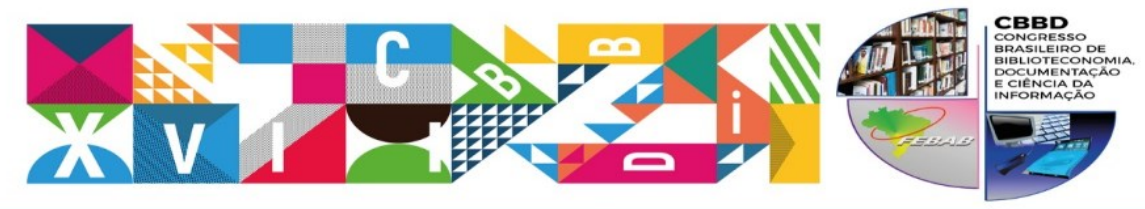

XXVII CONGRESSO BRASILEIRO DE BIBLIOTECONOMIA, DOCUMENTAÇÃO E CIÊNCIA DA INFORMAÇÃO

TEMA CENTRAL : Objetivos para o Desenvolvimento Sustentável das Naçōes Unidas:
como as bibliotecas podem contribuir com a implementaçăo da Agenda 2030

Competência em Informação: Pesquisas e Práticas no Rio de Janeiro que reuniu pesquisadores, profissionais e alunos para debater sobre a temática.

Entretanto, na fase de execução houve ajustes no cronograma em virtude de várias paralizações, além da greve que a escola (pública federal) participou. Tais acontecimentos fizeram com que a avaliação fosse prejudicada em partes, porque alguns alunos e professores já não compareciam à escola. Na etapa de execução, as duas últimas atividades também foram alteradas porque alguns espaços do colégio estavam impossibilitados de uso. De qualquer forma, pela avaliação dos alunos da UNIRIO, pela equipe da biblioteca do Pedro II, pelos alunos e professores do Colégio Pedro II o projeto obteve êxito e conseguiu atingir os propósitos estabelecidos.

Outra dificuldade percebida durante a execução foi em relação ao engajamento dos professores, seria importante capacitá-los e também pensar formas de conscientização sobre a participação no programa de forma prévia para que as ações fossem melhor executadas com a colaboração deles.

Ficou evidente a importância para que o projeto tenha continuidade em todas as turmas, principalmente fazendo parte do planejamento da equipe docente e da biblioteca do Colégio Pedro II, com vistas a dar oportunidade para que outros alunos desenvolvam as competências de uso, busca, seleção, avaliação, análise, interpretação, comunicação da informação, pois proporcionam benefícios ao longo da vida, pois exige uma aprendizagem continuada. Acredita-se que, dessa forma, será possível por meio de um trabalho colaborativo e interdisciplinar entre bibliotecários, professores e coordenações pedagógicas das escolas, a possibilidade de formar cidadãos com maior consciência crítica, reflexiva para lutar por uma sociedade mais justa, democrática e igualitária.

\section{REFERÊNCIAS}

ALVES, Fernanda Maria Melo; ALCARÁ, Adriana Rosecler. Modelos e experiências de competência em informação em contexto universitário. Encontros Bibli: Revista Eletrônica de Biblioteconomia e Ciência da Informação, Florianópolis, v. 19, n. 41, p. 83-104, set./dez., 2014. Disponível em: <https://periodicos.ufsc.br/index.php/eb/article/view/15182924.2014v19n41p83> Acesso em: 6 out.2017. 


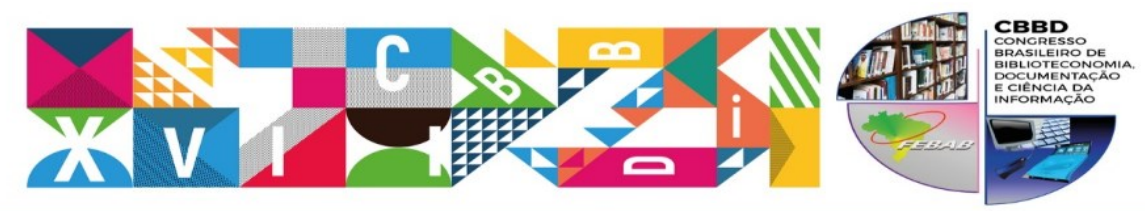

XXVII CONGRESSO BRASILEIRO DE BIBLIOTECONOMIA,

DOCUMENTAÇÃO E CIÊNCIA DA INFORMAÇÃO

TEMA CENTral: Objetivos para o Desenvolvimento Sustentável das Naçōes Unidas:

pressupostos para as estratégias de trabalho em aula. 10. ed. Joinville, SC: UNIVILLE, 2012.

BELLUZZO, Regina Baptista. Competências na era digital: desafios tangíveis para bibliotecários e educadores. ETD: Educação Temática Digital, Campinas, v. 6, n. 2, p. 30-50, jun. 2005. Disponível em: <https://periodicos.sbu.unicamp.br/ojs/index.php/etd/article/view/772/787>. Acesso em: 28 nov. 2017.

BELLUZZO, Regina Célia Baptista. Curso de Competência em Informação. 2011. Slides.

CAMPELLO, Bernadete. A competência informacional na educação para o século XXI. In: CAMPELLO, Bernadete et al. Biblioteca escolar: temas para uma prática pedagógica. Belo Horizonte: Autêntica, 2002. p. 09-11.

CAMPELLO, Bernadete et al. Biblioteca escolar: temas para uma prática pedagógica. Belo Horizonte: Autêntica, 2002.

CAREGNATO, Sônia Elisa. O desenvolvimento de habilidade informacionais: o papel das bibliotecas universitárias no contexto da informação digital em rede. Revista de

Biblioteconomia e Comunicação, Porto Alegre, v. 8, p. 47-55, jan./dez. 2000. Disponível em: <http://eprints.rclis.org/11663/1/artigoRBC.pdf>. Acesso em: 28 nov. 2017.

CARTA de Marília. In: SEMINÁRIO DE COMPETÊNCIA EM INFORMAÇÃO, 3., 2014, Marília. [Documentos produzidos]. Marília: UNESP, 2014. Disponível em:

<http://www.lti.pro.br/userfiles/downloads/CARTA_de_Marilia.pdf>. Acesso em: 28 nov. 2017.

COLÉGIO PEDRO II. Projeto Político Pedagógico. Brasília: INP/MEC, 2002.

DUDZIAK, Elisabeth Adriana. Competência informacional: análise evolucionária das tendências da pesquisa e produtividade científica em âmbito mundial. Informação e Informação, Londrina, v. 15, n. 2, p. 01-22, jul./dez. 2010. Disponível em: <http://www.uel.br/revistas/uel/index.php/informacao/article/view/7045>. Acesso em: 28 nov. 2017.

DUDZIAK, Elisabeth Adriana. Information literacy: princípios, filosofia e práticas. Ciência da Informação, Brasília, DF, v. 32, n. 1, p. 23-35, jan./ abr. 2003. Disponível em: <http://www.scielo.br/pdf/ci/v32n1/15970.pdf>. Acesso em: 28 nov. 2017.

DURBAN ROCA, Glòria; PROLONGO, Ana Cid; GARCÍA GUERRERO, José. Programas para el desarrollo de la competencia informacional articulados desde la biblioteca escolar. Sevilla, 2012. Disponível em:

<http://www.juntadeandalucia.es/educacion/webportal/ishareservlet/content/9e344cdaa851-46bb-b6e1-07aced30d800/DR4BECREA.pdf>. Acesso em: 16 out.2017.

FURTADO, Renata Lira; ALCARÁ, Adriana Roseclér. Desenvolvimento e formação de competência em informação: um mapeamento de modelos, padrões e documentos. In:

ENCONTRO NACIONAL DE PESQUISA EM CIÊNCIA DA INFORMAÇÃO, 16., João Pessoa, PB, 2015. Anais... João Pessoa: UFPB, 2015. Disponível em:

<http://www.ufpb.br/evento/lti/ocs/index.php/enancib2015/enancib2015/paper/view/2918 /1040.> Acesso em: 6 nov. 2017. 


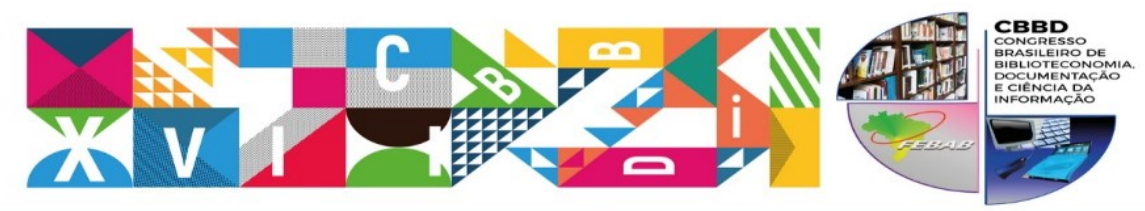

XXVII CONGRESSO BRASILEIRO DE BIBLIOTECONOMIA,

DOCUMENTAÇÃO E CIÊNCIA DA INFORMAÇÃO

TEMA CENTRAL: Objetivos para o Desenvolvimento Sustentável das Naçōes Unidas:
como as bibliotecas podem contribuir com a implementação da Agenda 2030

LAU, Jesús. Diretrizes sobre desenvolvimento de habilidades em informação para a aprendizagem permanente. [S. l.:] IFLA, 2008.

MARTINS, Jean Charles Racene dos Santos; MORAES, Margareth Lopes de; PAULA, Roberta Pereira da Silva de. Programa de competência em informação para a rede ametista de bibliotecas da CPRM - Serviço Geológico do Brasil: uma proposta e primeiras ações. In: SEMINÁRIO NACIONAL DE BIBLIOTECAS UNIVSERITÁRIAS, 19., Manaus, 2016. p. 1-2. Anais... Disponível em: <http://periodicos.ufam.edu.br/anaissnbu/article/view/3344>. Acesso em: 20 nov. 2017.

MARTINS, Valéria dos Santos Gouveia; BRACCHI, Regiane Alcântara; SEGNORELLI, Maria Helena. Modelagem e implantação de programa de competência em informação. Sínteses: Revista Eletrônica SIMTEC, Campinas, SP, n.6, p.126, set. 2016. Disponível em: <http://www.sbu.unicamp.br/seer/ojs/index.php/simtec/article/view/8338>. Acesso em: 6 out.2017.

MATA, Marta Leandro da. A competência informacional de graduando de Biblioteconomia da região sudeste: um enfoque nos processos de busca e uso ético da informação. 2009. $165 \mathrm{f}$. Dissertação (Mestrado em Ciência da Informação)—Programa de Pós-Graduação em Ciência da Informação, Universidade Estadual Paulista Júlio de Mesquita Filho, Marília, 2009.

ORGANIZAÇÃO DAS NAÇÕES UNIDAS PARA A EDUCAÇÃO, A CIÊNCIA E A CULTURA. Towards Information Literacy Standards. Paris, 2008. Disponível em:

<http://unesdoc.unesco.org/images/0015/001587/158723e.pdf>. Acesso em: 28 nov. 2017.

PEREIRA, Rodrigo. Desenvolvendo a competência em informação: resultados da prática no ensino fundamental. Rio de Janeiro: Interciência, 2015.

SPUDEIT, Daniela. Programas para desenvolvimento de competências informacionais: implementação, metodologias e avaliação. In: ALVES, Fernanda; CORREA, Elisa; LUCAS, Elaine. (Org). Competência em informação: políticas públicas, teoria e prática. Salvador: EDUFBA, 2016. p. 235-278. Disponível em: <https://repositorio.ufba.br/ri/handle/ri/22598>. Acesso em: 6 nov.2017.

URIBE TIRADO, Alejandro. 75 lições aprendidas de programas de competência em informação em universidades da Ibero-America: 2009-2013. REBECIN: Revista Brasileira de Educação em Ciência da Informação, São Paulo, v. 1, n. 2, p. 4-18, jul./dez. 2014. Acesso em: 14 nov. 2017. Disponível em:

<http://abecin.org.br/portalderevistas/index.php/rebecin/article/view/13/pdf > Acesso em: 28 nov. 2017.

VITORINO, Elizete; PIANTOLA, Daniela. Competência informacional: bases históricas e conceituais: construindo significados. Ciência da Informação, Brasília, DF, v. 38, n. 3, p. 130141, set./dez. 2009. Disponível em: <http://www.scielo.br/pdf/ci/v38n3/v38n3a09.pdf>. Acesso em: 28 nov. 2017.

VITORINO, Elizete Vieira; PIANTOLA, Daniela. Dimensões da Competência Informacional. Ciência da Informação, Brasília, DF, v. 40, n. 1, p.99-110, jan./abr. 2011. Disponível em: <http://www.scielo.br/pdf/ci/v40n1/a08v40n1.pdf>. Acesso em: 28 nov. 2017. 


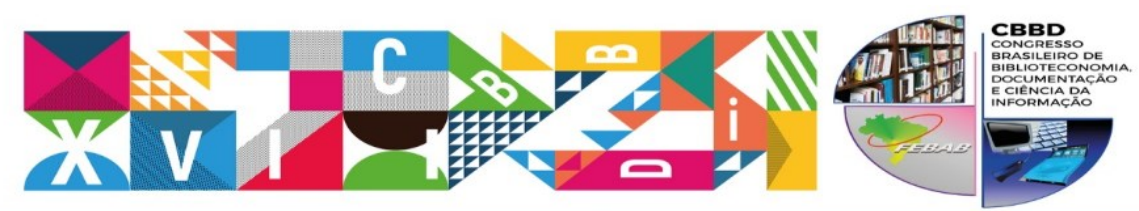

XXVII CONGRESSO BRASILEIRO DE BIBLIOTECONOMIA, DOCUMENTAÇÃO E CIÊNCIA DA INFORMAÇĀO

TEMA CENTRAL: Objetivos para o Desenvolvimento Sustentável das Naçōes Unidas:
como as bibliotecas podem contribuir com a implementaçăo da Agenda 2030

WERTHEIN, Jorge. A sociedade da informação e seus desafios. Ciência da Informação, Brasília, v.29, n.2, maio/ago., p. 71-77, 2000. Disponível em:

<http://revista.ibict.br/ciinf/article/view/889/924>. Acesso em: 28 nov. 2017.

\section{AGRADECIMENTOS}

Agradecemos a todos os alunos e professores envolvidos na realização do projeto que foi coordenado pelos professores Daniela Spudeit e Alberto Calil Júnior da UNIRIO. Houve a participação de alunos dos cursos de licenciatura e bacharelado em Biblioteconomia Alanna Freitas, Nathália Romeiro, Victor Rosa, Laíza Lima, Magno Evangelista, Claudia Souza, Mariana Acorse e Celina Almeida. Registramos um agradecimento especial às bibliotecárias do Pedro II Maria Conceição Dias e Marcia Feijão que viabilizaram a aplicação do projeto no colégio no decorrer do ano de 2015. 